\title{
Glucose-6-Phosphate 1-Dehydrogenase
}

National Cancer Institute

\section{Source}

National Cancer Institute. Glucose-6-Phosphate 1-Dehydrogenase. NCI Thesaurus. Code C16640.

Glucose-6-phosphate 1-dehydrogenase ( $515 \mathrm{aa}, \sim 59 \mathrm{kDa}$ ) is encoded by the human G6PD gene. This protein plays a role in pentose metabolism to produce NADPH. 